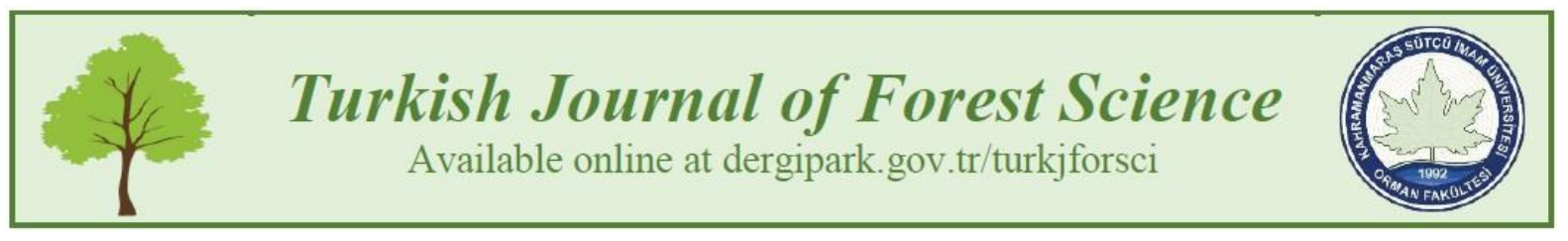

\title{
EVALUATION OF VISUAL SPATIAL INTELLIGENCE SKILLS OF FOREST INDUSTRY ENGINEERING STUDENTS
}

\author{
Emel ÖZTÜRK ${ }^{*}$, Emine Seda ERDINNLER ${ }^{1}$, Sedanur ŞEKER $^{1}$ \\ ${ }^{1}$ Department of Forest Industry Engineering, Faculty of Forestry, Istanbul University - Cerrahpaşa, Istanbul \\ *Corresponding author: emelozt@iuc.edu.tr
}

Emel ÖZTÜRK: https://orcid.org/0000-0002-2452-4912

Emine Seda ERDINNLER: https://orcid.org/0000-0002-7814-4333

Sedanur ŞEKER: https://orcid.org/0000-0002-7268-6385

Please cite this article as: Öztürk, E., Erdinler, E.S., \& Şeker, S. (2021) Evaluation of Visual Spatial Intelligence Skills of Forest Industry Engineering Students, Turkish Journal of Forest Science, 5(2), 496-515

\section{ESER BILGISI / ARTICLE INFO}

Araştırma Makalesi / Research Article

Geliş 5 Agustos 2021 / Received 5 August 2021

Düzeltmelerin gelişi 2 Eylul 2021 / Received in revised form 2 September 2021

Kabul 20 Eylul 2021 / Accepted 20 September 2021

Yayımlanma 31 Ekim 2021 / Published online 31 October 2021

\begin{abstract}
In this study, it was aimed to reveal three-dimensional visual interpretation skills in the example of Istanbul University-Cerrahpaşa, Faculty of Forestry students, one of the most preferred Forest Industry Engineering programs in Turkey. To that end, findings on how the three-dimensional thinking, perception and interpretation skills of Technical Drawing module students taught in the First Term of the Forest Industry Engineering Department changed when they completed the module at the end of the term is chiefly examined. It was aimed to observe the change by questioning the students with two different questionnaires at the beginning and end of the term. Visual figure questions from the two- and three-dimensional perception, comparison and matching of objects, as well as questions assessing their interest in the module and computers were adressed. At the end of the term, the percentage of students who provided the correct answer to the question of matching the views of the parts whose figures were provided increased by approximately $11 \%$ from $37.04 \%$ to $48.15 \%$. The rate of students who answered all 3D views correctly (i.e. 9/9) in the question in which the 3D view of the object was evaluated from different angles was $63 \%$ at the beginning of the term, while this rate increased to $88.88 \%$ at the end of the term. The findings revealed that, in the evaluation made at the end of the term, the level of success of the first year university students in thee-views and three-dimensional assessment questions increased compared to the beginning of the term.
\end{abstract}

Keywords: Spatial intelligence, technical drawing, forest industry engineering students, 3D visual interpretation, 3-D thinking, university students 


\section{ORMAN ENDÜSTRİ MÜHENDISSLİĞİ ÖĞRENCILERINİN GÖRSEL UZAMSAL ZEKÂ BECERILERININ DEĞERLENDİRILMESI}

ÖZET: Bu çalışmada, Türkiye'nin en fazla tercih edilen Orman Endüstri Mühendisliği bölümlerinden biri olan İstanbul Üniversitesi- Cerrahpaşa, Orman Fakültesi öğrencileri örneğinde, üç boyutlu görsel yorumlama becerilerinin ortaya konması amaçlanmıştır. Orman Endüstri Mühendisliği bölümü I. Yarıyılında okutulan Teknik Resim dersi öğrencilerinin üç boyutlu düşünebilme, algılama ve yorumlama becerilerinin dönem sonunda dersi tamamladıklarında nasıl değiştiğine dair bulgular incelenmiştir. Öğrencilere dönem başında ve dönem sonunda iki farklı anket formu ile sorgulama yapılarak değişimin gözlenmesi amaçlanmıştır. Objelerin iki ve üç boyutlu algılanması, karşılaştırılması ve eşleştirilmesi tarzından görsel şekil soruları ile derse / bilgisayar konularına olan ilgilerinin değerlendirildiği sorular sorulmuştur. Perspektif resimleri verilen parçalara ait görünüşlerin eşleştirilmesi sorusunda, dönem sonunda tam doğru cevap veren öğrencilerin oranının \%11 oranında artarak $\% 37,04$ 'ten, $\% 48,15$ 'e yükselmiştir. 3 boyutlu perspektifi verilen objeye farklı aç1lardan bakışın değerlendirildiği soruda ise perspektif görünüşlerinin tamamını (9 / 9) doğru yanıtlayan öğrencilerin oranı dönem başında \%63 iken, dönem sonunda bu oran artarak \%88,88' e yükselmiştir. Elde edilen bulgular, dönem sonundaki yapılan değerlendirmede, üniversite birinci sınıf öğrencilerinin üç görünüş ve üç boyutlu değerlendirme sorularında başarı seviyesinin dönem başına göre arttığı görülmüştür.

Anahtar kelimeler: Uzamsal zekâ, teknik resim, orman endüstri mühendisliği bölümü öğrencileri, 3D görsel yorumlama, 3 boyutlu düşünebilme, üniversite öğrencileri

\section{INTRODUCTION}

Intelligence could be defined as the capacity to learn, utilize what has been learned and produce new solutions what has been learned, or the ability to think and reason; and the ability to question and draw conclusions. When discussing intelligence, which is a general definition, the prudent approach would be evaluating it in more than one way. Multiple intelligence theory is an approch developed by the American psychologist Howard Gardner, who conducts scientific studies at Harvard University. According to this approach, human intelligence is divided into eight subcategories and research has already begun on the 9th subcategory. The existing 8 subcategories consist of intelligence types that reveal -or classify-in which areas a person can utilize his/her intelligence more effectively. According to Gardner's multiple intelligence theory, each individual has special talent areas and a unique way of utilizing their inteligence. To that end, the theory of multiple intelligences contend that intelligence is unique but divided into classes (i.e. there are types of intelligence). However, he also indicates that each type of intelligence is dynamic and can be further developed.

Spatial intelligence is a type of intelligence that is related to visuality and is actually called visuospatial. The visuality mentioned here is related to both seeing and visualization called the "mind's eye". It is one of the first areas of development in the mental sense because people see from the moment they are born. Memorizing what is seen, visualizing what is told, sizing and constructing visual designs are among the visuospatial intelligence skills. Visual intelligence, which is at a basic level in certain individuals, can be observed more cleaerly in individuals who have proven themselves in artistic fields. 
Learning three-dimensional spatial concepts with the help of two-dimensional drawings in traditional teaching environments actually creates a kind of 'cognitive disability' for students. The development of spatial intelligence of students has an important role in overcoming this cognitive disability and eliminating its negative effects (Alcaniz et al., 2010).

The first study on spatial ability was done by Thurstone in 1938. Thurstone (1938) studied mental ability and introduced the concept of "space" (Kayhan, 2005). On the other hand, Sternberg (1990) defined spatial ability as one of the mental abilities, describing it as the revitalization and rotation of objects in the mind. French (1951), furthermore, defined spatial ability as the ability to visualize, grasp and move objects in 3-D space in mind (McGee, 1979). Linn and Petersen (1985) defined spatial ability as the ability to represent, transform, create and recall symbolic and non-linguistic information. Apart from the above, spatial ability indicated by Olkun and Altun (2003) contains skills related to the use of the geometric form. Kayhan (2005) defined spatial ability as visual manipulation, reorganization or explanation of relationships.

Ferguson (1992) defines engineering drawings as a means by which a vision in one person's mind might be conveyed by material means drawings across space and time to another person's mind. After briefly revisiting their historical evolution, Ferguson (1992) states that drawings can quickly yield a great deal of information, but only to readers who know how to extract it. In addition to the foregoing, he adds that "... the best way to learn how to read drawings, and probably the only fully effective way, is to learn how to make drawings." (Ferguson, 1992).

The field of spatial visualization is rather unclearly defined and its notion, from the perspective of education, psychology and technical science, is characterized by certain conceptual and terminological inconsistencies. The research on the usage of spatial visualization is usually focused on particular aspects which do not represent the topic in its whole complexity. Mainly, there are surveys on spatial imagination and its development, or the correlation between spatial imagination and successfully learning certain subjects (Górska, 2005; Sorby, 2007). Some authors such as Schanbel and Kvan (2003) also reveal that the manner in which the mental representation of the perceived reality is constructed, especially the mental models, differ significantly in comparable groups of individuals, depending on whether planar or spatial models are used during the processes of creating such models representing the given object. Furthermore, Esparrachiari (2005) also conducted surveys comparing the results of instruction, using either planar or spatial visualization while Roussou (2000) conducted surveys on virtual reality or virtual learning environment. However, it would be prudent to state that spatial visualization as a scientific concept has not been fully acknowledged yet.

In addition to the foregoing, Gardner (2011) suggests that each individual has a different intelligence profile and developed the theory of multiple intelligences as explained in his seminal book, Frames of Mind: The Theory of Multiple Intelligences, highlighting the skills, learning styles and tendencies of individuals. Gardner (2011) proposed eight aspects of intelligence instead of two and identified such eight intelligences as verbal-linguistic, logicalmathematical, visual-spatial, bodily-kinesthetic, musical-rhythmic, interpersonalintrapersonal, individual/existential, and naturalistic. Visual-spatial intelligence encapsulates the ability of individuals to objectively observe, perceive and evaluate their environment. Individuals with strong visual/spatial intelligence learn better by studying with pictures, lines and colors. Professions requiring maximum level of visual/ spatial intelligence are architects, pilots, mariners, artists, sculptors, scouts, hunters, designers and decorators (Gardner, 2011). 
Yazic1 (2016) examines the relationship between the cognitive styles and visual-spatial intelligence of first-year architecture students. The cognitive styles of students were determined using the "levels" dimension of the Thinking Styles Inventory. Accordingly, the assessment of students' 2D and 3D perception skills was based on their performance in answering a series of questions about 3D projections and 3D views. In conclusion, students' performance in answering questions was found to be significantly related to their cognitive styles.

In their seminal study, Machuca et al. (2019) analyzed the behavior of users with different spatial abilities while drawing in VR. Accordingly, results show that there are different types of behavior that affect different aspects of sketches. Machuca et al. (2019) also found that the user's spatial ability affects the shape of the drawing, but not the line precision. Finally, they make recommendations for designing $3 \mathrm{D}$ drawing interfaces.

In another study conducted by Berkan et al. (2020), the contribution of the "Architectural Presentation Techniques" course to spatial skills was examined by taking into account the spatial experiences and innate abilities of the students before architectural education. Pre-test and post-test research were applied and analyzed with Statistical Packages for Social Sciences (SPSS) version 18 software. Pre-test and post-test results concluded that a significant improvement was observed between spatial visualization-spatial perception and spatial orientation tests, while no significant progress was observed between mental rotation and spatial relationship-mental rotation tests. The evaluation of the data shows that the course in question is highly effective in developing spatial skills in total and in the context of spatial visualization and spatial orientation, and that skills can be developed through education (Berkan et al., 2020).

Furthermore, Skagerlund et al. (2020) presented a study utilizing hierarchical regression analysis to investigate which cognitive skills predict general decision-making competence in adults. A cognitive test battery consisting of abilities such as general intelligence, application functions, numerical skills, visual-spatial ability and time perception was administered to 182 participants. The results show that both general intelligence, which is consistently the strongest determinant, and numerical information independently contribute to overall decision-making competence (Skagerlund et al., 2020).

Background spatial ability is a unique type of intelligence which can be distinguished from other forms of intelligence and plays an important role in an individual's success in many academic fields, especially in this age of technology. Teaching-assisted 3D technology can display stereo graphics and enable students to understand the geometric structure and properties of the graphics. Spatial ability includes several aspects. Li et al.'s (2020) study aims to discover an effective method of spatial ability development for senior high school students and to develop students' independent inquiry skills (Li et al., 2020).

In addition to the above, Castro-Alonso et al. (2019) show a two-way relationship between university biology education and spatial ability. While the main focus is on university biology and spatial abilities of mental rotation and mental folding (spatial visualization), the authors presented findings showing that these spatial abilities affect university biology learning and achievement from textual and visual materials. They also revealed correlational studies and experiments showing that university biology education positively affects mental rotation and mental folding (Castro-Alonso et al., 2019). 
Furthermore, Kauffman (2004) argues that working directly with three-dimensional figures can provide a better and faster understanding and comprehension of complex spatial problems and spatial relationships than traditional methods. In the same vein, both Haniff and Baber (2003), as well as Wang and Dunston (2006) contend that augmented reality interfaces provide a more effective and different learning environment for teaching three-dimensional objects.

Hsi et al. (1997) interviewed a group of engineering instructors and engineers working in industry. They agree that spatial reasoning skills were important and could help engineering students. Moreover, it has been empirically demonstrated that visualization is a moderately good predictor of success in modules such as Engineering Drawing (Hsi et al. (1997); G. Prieto et al. (2002a); (2002b); Saito et al. (1998)).

Students present difficulty with the basic concepts of technical drawings and the ability to visualize spatially. To fill this gap in the literature, Valera et al., 2021) aimed to examine the effect of a 3D solid object as a teaching aid strategy to improve spatial visualization ability among 30 Technology and Drawing students at a community college in Misamis Oriental, Philippines. In this study, an explanatory mixed method using a single group pretest-posttest design was used to collect quantitative data. Then, personal interviews were conducted to collect data to explain the numerical results. Research tools were adapted from the Mental Rotation Test (MRT), the Purdue Spatial Visualization Test: Visualization of Rotations, and the Differential Aptitude Test: Space Associations (DAT:SR). The findings of this study revealed that the $3 \mathrm{D}$ solid object significantly improved students' visual spatialization abilities as vision, depth perception and tactile senses were activated in their classrooms. Curriculum planning and recommendations for future work are discussed in this paper (Valera et al., 2021). In order to draw architectural spaces, one must have the ability to mentally visualize and manipulate them, which leads us to the concept of spatial skills; but it also requires developing a spatial perception to be able to express it in drawings. In this context, Gómez -Tone et al. (2021) analyzed the development of spatial skills through full-scale drawing of architectural spaces in virtual immersive environments and discussed spatial perception with reference to the capture of spatial sensations in virtual immersive environments. It was found that the training significantly improved orientation, rotation, and visualization, and the sensory journey and experimentation of architectural spaces realistically modeled in immersive virtual reality environments allowed the same feelings the designer was initially trying to convey (GómezTone et al., 2021).

In addition to the foregoing, in their seminal study, Adiska et al. (2021) aimed to determine the effect of 3D visualization on learning nucleophilic substitution reaction in order to improve students' critical thinking abilities. In this study, quasi-experimental pre-test and post-test design were utilized. 68 students from two different universities in West Java participated in this study. The critical thinking ability test tool consisted of 9 multiple-choice questions with their reasons. The results revealed that learning to use 3D visualization in the nucleophilic substitution reaction can improve students' critical thinking ability (Adiska et al., 2021).

Students often have difficulty understanding abstract concepts in chemistry and have low spatial abilities, especially in visualizing intermolecular interactions at a microscopic level. Therefore, Rahmavati et al. (2021), while examining the molecular geometry curriculum topic, aims to analyze students' spatial abilities using a 3D virtual representation. A qualitative methodology was used to analyze students' spatial abilities while undertaking learning activities using 3D virtual representation. D Learning was carried out in three stages; engage, 
research and explain. The results of the study show that the students' spatial orientation skills are low, and their abilities in spatial relations including mental manipulation and rotation of $2 \mathrm{D}$ or $3 \mathrm{D}$ objects are more developed.

In this study, it is aimed to reveal three-dimension visiual interpretation skills in the example of Istanbul University-Cerrahpaşa, Faculty of Forestry students, in one of the most preferred Forest Industry Engineering departments in the country. It was examined how the threedimensional thinking, perception and interpretation skills of the Technical Painting module students taught in the First Term (i.e. fall) of the Department of Forest Industry Engineering changed both at the beginning and end of the term when they completed the module.

\section{MATERIALS AND METHODS}

This study was carried out with the aim of examining the three-dimensional visual interpretation and evaluation skills (visual spatial intelligence) of the forest industry engineering department students. The study was handled within the scope of the technical drawing module, which the students encountered in their first year of undergraduate education. Technical drawing module is one of the three-dimensional thinking and interpretation skills oriented modules such as computer-aided design, furniture and joinery constructions, furniture industry modules in the undergraduate syllabus of the forest industry engineering department. The experimental study was conducted with 27 first year students of the Department of Forest Industry Engineering at Istanbul University-Cerrahpasa who were registered to the Technical Drawing module which is quite similar to engineering graphics modules in engineering programs during the 2019-2020 Fall Semester. Participation in this study was voluntary and the participants were informed about the study and its purpose.

Total number of students enrolled in the Technical Drawing module in the 2019-2020 (Fall) academic year was 39 .

Due to the fact that the students who repeated the module (i.e. fail) and were not required to attend the class were not physically present in the classroom, the rate of participation in this study was $69,23 \%$ in accordance with the class size.

The questionnaire was conducted in two stages, namely at the beginning of the fall academic year and at the end of the same semester. Questions were designed/prepared to evaluate student's two- and three-dimensional perception and visual interpretation skills. The questions were prepared in different difficulty levels (i.e. from easy to difficult), especially taking into account that the knowledge and experience of the students varied.

The first stage of the study was applied to Forest Industry Engineering first year students in the first lesson of the Technical Drawing module (i.e. first week) and the second stage of the study was applied at the beginning of the final exam (i.e. 14th week). At the beginning of this study, the students were informed on the research and its purpose while explanations were also provided to the questions addressed by the students.

As explained above, the first stage was conducted at the beginning of the semester, before the lesson started. The questions at this stage consisted of 4 parts. The first part consisted of demographic questions. The second part consisted of questions pertaining the school and the 
module. The students were asked quesitons about their interest in computer games and computer software, how often they play computer games and what kind of games they play. The purpose of these questions was to understand whether computer games and software were related to three-dimensional understanding and thinking skills. The questions in the third part were about the objects that were given as front view, top view, side view and their 3D views. The questions in the fourth part were about finding the same $3 \mathrm{D}$ views from different angles. As indicated above, the second stage was conducted at the end of the semester after the lesson. The questions at this stage also consist of 4 parts which are all the same as the first questionnaire.

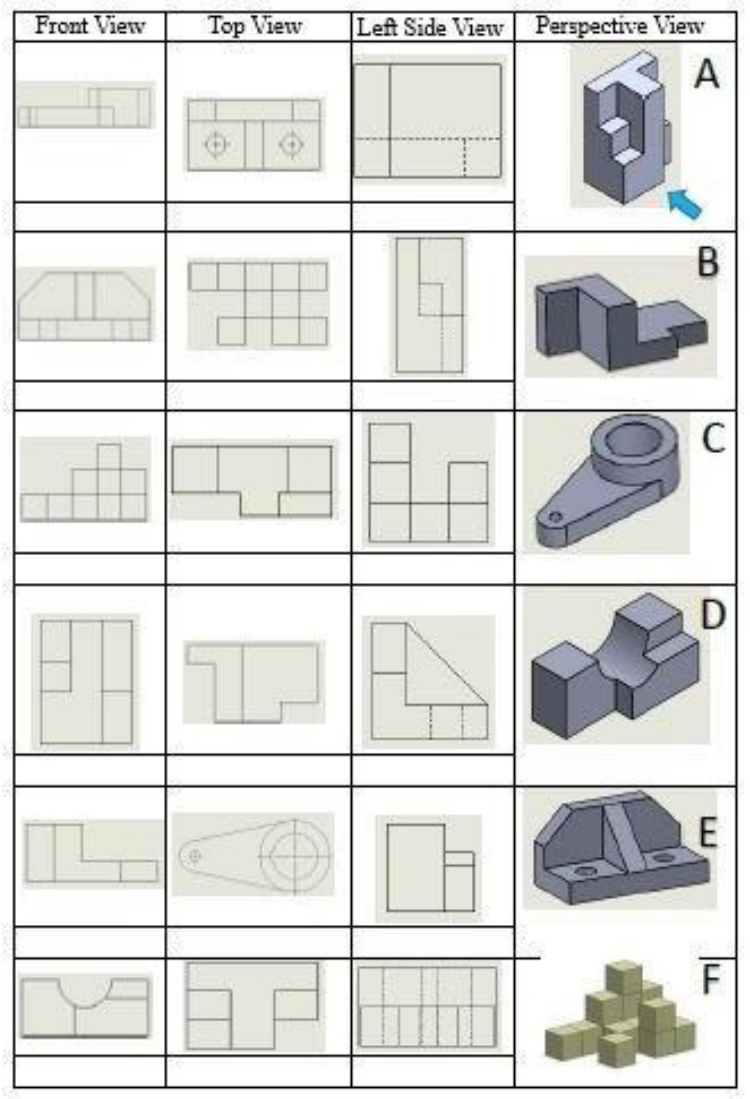

Figure 1: An Example For Which 3D Views And 3-Views Of The Parts Were Given For Question 1.

Figure 1 - Question 1: In this question, three-dimensional 3D views of 8 different objects (i.e. A, B, C, D, E, F) were provided. Three view drawings of these 3D views (from/top/left side) were mixed in the boxes on the side. The students were asked to find out which 3D views belonged to these mixed 3-view drawings. In this question, the students were asked to match 18 figures. (Figure 1)

Figure 2 - Question 2: In the second visual question, mixed 3D views of 3 different parts were given to the students. 3D drawings belonging to each piece were asked to be matched. (Figure 2) 


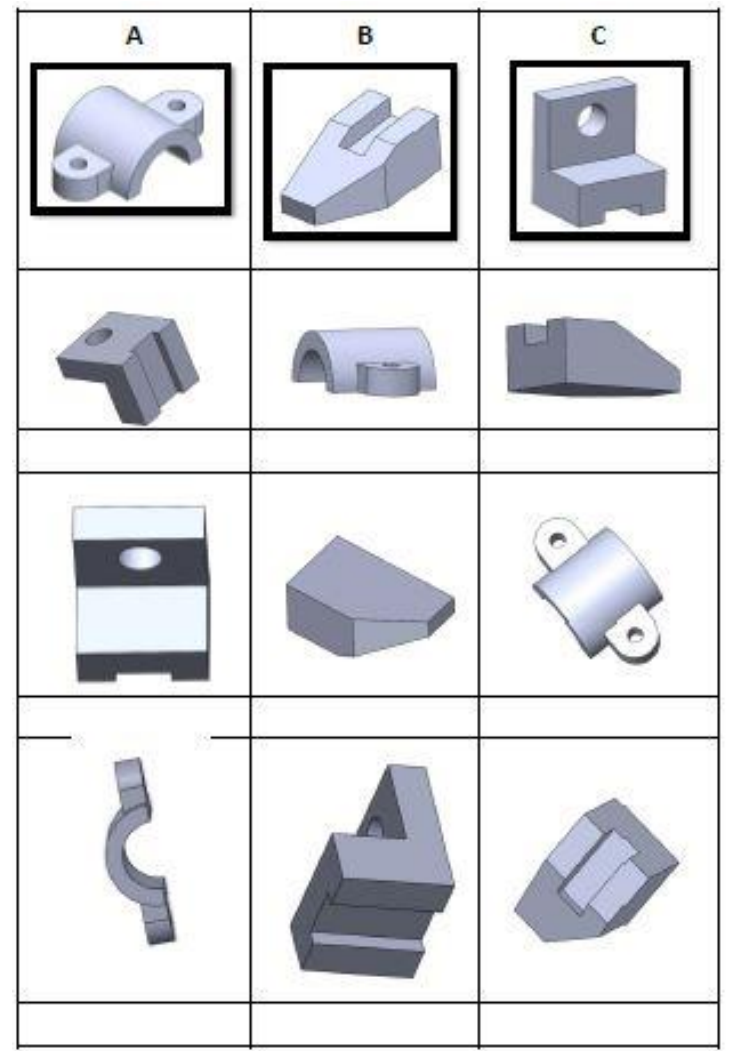

Figure 2: Mixed 3D Views Of 3 Different Parts Were Given For Question 2.

In the end-of-term survey, two visual questions made at the beginning of the term were repeated. In addition to these questions, two additional visual questions were applied to measure the visual development of the students through out the year.

Question 3: Mixed 3D views of 4 parts in the visual question 3 in the study were given. The students to whom the questionnaire was applied were asked to match the 3D views of the piece. In this question, the parts were chosen from the parts that were very similar to each other. It has been prepared in a structure that requires students to analyze the objects in more detail. (Figure 3) 


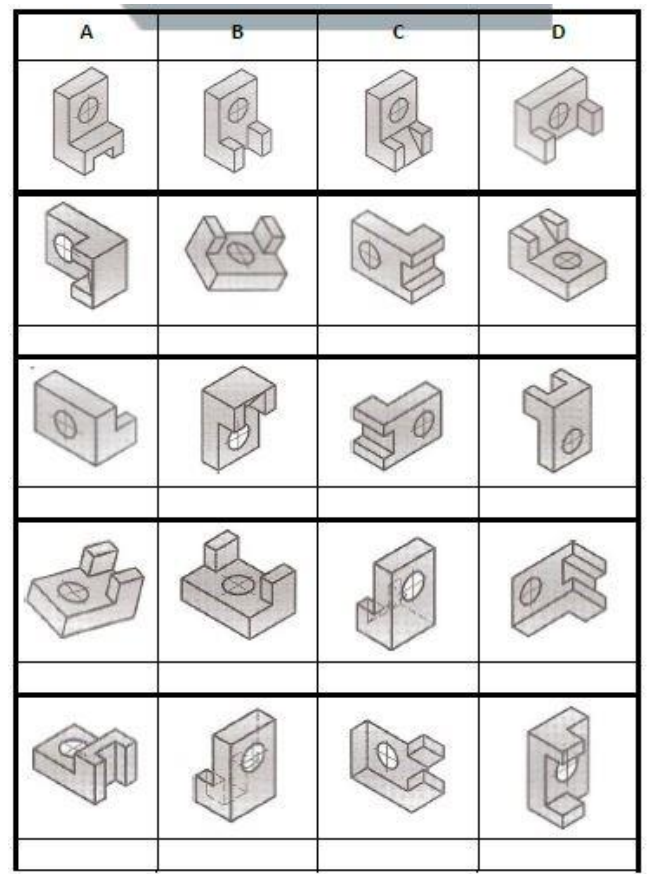

Figure 3: 3D Views And An Example Using 3D View Matching Given For Question 3.

Question 4: For question 4 in the study, four different parts were given. The front view, top view and left side view of these 4 different parts were given in a mixed combination. Students were asked to match the appearances and determine the appropriate view labels of the parts. ( Figure 4)

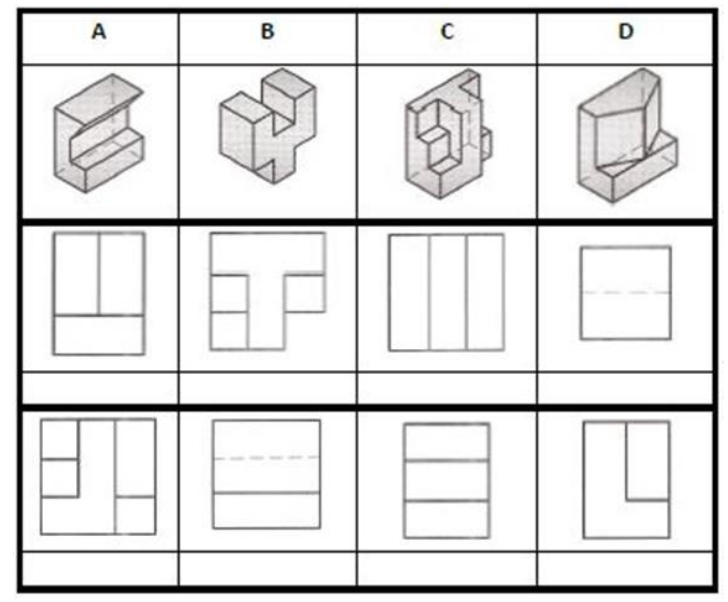

Figure 4: An Example For Which 3D Views And Views Of The Parts Were Given For Question 4.

\section{RESULTS}

The results of the study conducted in Istanbul University-Cerrahpaşa, Faculty of Forestry, Department of Forest Industry Engineering in the first year technical drawing module in two different time periods, namely at the beginning and at the end of the semester are as follows: A total of 27 students, 17 male $(62.96 \%)$ and 10 female $(37.03 \%)$ participated in the questionnaire. 
The majority of the students $(74,17 \%)$ who took the module and participated in the survey were born in 1999 and 2000. Students born in 1999 constitute 40.74\%, students born in 2000 constitute $33.33 \%$, while the remaining $25.9 \%$ were born in either 1997 and 1998 . The average age of the students were 21 .

The province where $85 \%$ of the students participating in the survey lived before university was Istanbul. Other provinces were Kütahya, İzmir, Çanakkale and Kocaeli.

The distribution of the high schools from which the participating students gradutated is as follows: 48.15\% Anatolian High School (official high schools teaching foreign language), 14.81\% Private High Schools, 14.81\% High School (official and daytime high schools), 11.11\% Multi-program High Schools, 7.4\% Religious Vocational Schools and 3.7\% Technical High Schools.

Table 1. Evaluations For Department, Module And Computer Use (At The Beginning Of The Semester-Survey 1)

\begin{tabular}{|c|c|c|}
\hline Reason for Choosing OEM Faculty & Frequency & Percentage $(\%)$ \\
\hline $\begin{array}{l}\text { I chose it consciously because I knew the } \\
\text { department. }\end{array}$ & 8 & 29,62 \\
\hline I chose it because I was undecided. & 7 & 25,93 \\
\hline $\begin{array}{l}\text { I chose Istanbul University because of its } \\
\text { reputation. }\end{array}$ & 7 & 25,93 \\
\hline Other & 5 & 18,52 \\
\hline $\begin{array}{l}\text { Did you take a Technical Drawing module } \\
\text { before univeristy? }\end{array}$ & Frequency & Percentage $(\%)$ \\
\hline Yes & 1 & 3,70 \\
\hline No & 26 & 96,30 \\
\hline $\begin{array}{l}\text { How many times did you take the Technical } \\
\text { Drawing module? }\end{array}$ & Frequency & Percentage (\%) \\
\hline First time & 24 & 88,88 \\
\hline Second time & 3 & 11,11 \\
\hline Level of interest in computer games & Frequency & Percentage (\%) \\
\hline Excessively & 3 & 11,11 \\
\hline Considerable & 6 & 22,22 \\
\hline Moderate & 7 & 25,93 \\
\hline Sometimes & 4 & 14,81 \\
\hline Very Rarely & 7 & 25,93 \\
\hline Level of interest in computer softwares & Frequency & Percentage $(\%)$ \\
\hline Excessively & 1 & 3,70 \\
\hline Considerable & 6 & 22,22 \\
\hline Moderate & 9 & 33,33 \\
\hline Sometimes & 2 & 7,41 \\
\hline Very Rarely & 9 & 33,33 \\
\hline Frequency of Playing Computer Games & Frequency & Percentage $(\%)$ \\
\hline More than 2 hours a day & 7 & 25,93 \\
\hline No more than 2 hours a day & 9 & 33,33 \\
\hline Several times a week & 3 & 11,11 \\
\hline Several times per month & 4 & 14,81 \\
\hline Never & 4 & 14,81 \\
\hline Computer Games & Frequency & Percentage $(\%)$ \\
\hline Action & 11 & 40,74 \\
\hline Sport & 10 & 37,04 \\
\hline Strategy & 8 & 29,63 \\
\hline Information & 7 & 25,93 \\
\hline Educative & 7 & 25,93 \\
\hline Race & 7 & 25,93 \\
\hline Talent & 6 & 22,22 \\
\hline
\end{tabular}




\begin{tabular}{lll} 
Puzzle & 6 & 22,22 \\
\hline Intelligence & 6 & 22,22 \\
\hline Words & 5 & 18,52 \\
\hline Adventure & 5 & 18,52 \\
\hline Not playing any games & 4 & 14,81 \\
\hline Arcade & 3 & 11,11 \\
\hline Simulation & 3 & 11,11 \\
\hline Other & 2 & 7,41 \\
\hline Classic & 0 & 0,00 \\
\hline
\end{tabular}

The reasons for students to choose the Department of Forest Industry Engineering were respectively: $29.62 \%$ I chose it conciously because I knew the department, $25.93 \%$ I chose it because I was undecided, $25.93 \%$ I chose it because of the Istanbul University's reputation and $18.52 \%$ for other reasons (enough grades to apply, to make a selection, because it is an engineering programme, etc.) (Table 1).

$96.3 \%$ of the students have never taken a technical drawing or similar module from another educational institution (high school, module, etc.) other than the faculty. Those who were to take the Technical Drawing module for the first time were $88.88 \%$, and the rate of those who were taking the course for the second time were $11.11 \%$, as illustrated in Table 1 above.

Looking at the level of interest in computer games, it is seen that $11.11 \%$ were excessively interested while $22.22 \%$ has a considerable amount of interest. Furthermore, $25.93 \%$ of the participants indicated that their interest was moderate, while $14.81 \%$ and $25.9 \%$ them respectively indicated sometimes or very rarely. The most played game genre was action games with $41 \%$. This was followed by sports, strategy, information, educative and racing games respectively, with a rate of $25 \%$ and above (Table 1 ).

In addition to the foregoing, the level of interest in computer software was as follows: excessive (3.7\%), 22.22\% (considerable), 33.33\% (moderate), $7.41 \%$ (sometimes) and 33.33 (very rarely). It was also observed that $59.25 \%$ of the students had a medium or higher level of interest in computure sofware, as provided under Table 1.

The frequency of students playing computer games was as follows: more than 2 hours a day $(14.81 \%)$, no more than 2 hours a day (14.81\%), several times a week $(11.11 \%)$, several times a month $(33.33 \%)$ and never $(25.93 \%)$. It was also monitored that $59.26 \%$ of the students play computer games for a maximum of 2 hours and more than 2 hours a day as illustrated in Table 1.

Furthermore, the students were asked to evaluate their level of interest in the Technical Drawing module in the range of 0-100 points. According to the responses provided, the average level of interest of the students in the Technical Drawing Module was 60/100. While the average of interest level of female students was determined as 73/100, the average of interest level of male students was only 52.5/100. At the end of the semester (i.e. the second questionnaire), the average level of interest of the students in the Technical Drawing module increased to 70.63/100. While the average of interest level of female students was monitored as $84.7 / 100$, the average of interest level of male students was $62.35 / 100$ points. At the end of the semester, it was observed that the students' interest in the module increased by approximately 10 points. Table 2 below reveals the distribution of students' interest levels between 0-100 points. 
Table 2. Evaluation Of The Level Of Interest In The Technical Drawing Module

\begin{tabular}{c|cc|cc}
\hline & \multicolumn{2}{|c|}{ Questionnaire 1 (beginning of } & Questionnaire 2 (end of the term) \\
\hline $\begin{array}{c}\text { Level of } \\
\text { Interest } \\
(\mathbf{0 - 1 0 0 )}\end{array}$ & Frequence & $\begin{array}{c}\text { Percentage } \\
(\%)\end{array}$ & Frequency & $\begin{array}{c}\text { Percentage } \\
(\%)\end{array}$ \\
\hline $81-100$ & 4 & 14,81 & 7 & 25,93 \\
\hline $61-80$ & 9 & 33,33 & 15 & 55,55 \\
\hline $41-60$ & 10 & 37,04 & 2 & 7,41 \\
\hline $21-40$ & 1 & 3,70 & 2 & 7,41 \\
\hline $0-20$ & 3 & 11,11 & 1 & 3,70 \\
\hline
\end{tabular}

To the question whether Technical Drawing module requires a special talent, $40 \%$ of the female students answered yes and $60 \%$ of them answered no while $47 \%$ of male students responded as yes and 53\% of them responded as no. Looking at the average, it is seen that the rate of students who think that the Technical Drawing module requires special talent was $44.44 \%$, and the rate of students who think that it does not require special talent was $55.56 \%$. In other words, more than half of the students believe that being successful in the Technical Drawing module does not solely depend on a special talent. Among the students who said yes to the quesiton of whether special talent is required, male students were interested by 45,63 point evaluation for level of interest while it was higher in the girls with 61.5 points. On the other hand, among the students who answered no the question of whether special talent is required, female students were by 80.33 points interested while male students were 58.66 points interested. In the second questionnaire conducted at the end of the term, for the question of whether a special talent is required for the Technical Drawing Module, 50\% students answered yes and the other half answered no. This ratio was $29.41 \%$ yes and $70.59 \%$ no for male students. To that end, in terms of the average at the end of the semester, the rate of students who believe that the Technical Drawing module requires special talent was $37.04 \%$, and the rate of students who think that it does not require special talent was $62.96 \%$. Among the students who answered yes to the question of whether it requires a special talent, the male students who evaluated level of interest as 37 points, while girls were interested by evaluation of 76 points. On the other hand, among the students who answered no to the question of whether special talent is required, the female students evaluated with an average of 93,4 points of interest level while this value was observed as 72.93 for male students (Table 3).

Table 3. The Evaluation Of The Question Of Whether "Special Talent Is Required For Technical Drawing Module"

\begin{tabular}{c|cc|cc}
\hline & \multicolumn{2}{|c|}{$\begin{array}{c}\text { Questionnaire 1 (at the beginning of } \\
\text { the term) }\end{array}$} & \multicolumn{2}{c}{$\begin{array}{c}\text { Questionnaire 2 (at the end of the } \\
\text { term) }\end{array}$} \\
\hline $\begin{array}{c}\text { Is special talent } \\
\text { required? }\end{array}$ & Frequency & Percentage (\%) & Frequency & Percentage (\%) \\
\hline No & 15 & 55,55 & 17 & 62,96 \\
\hline Yes & 12 & 44,44 & 10 & 37,03 \\
\hline
\end{tabular}

To the question of "To what extent do you think the Technical Drawing module will contribute to other vocational modules you will take during your engineering education?", $14.81 \%$ of the students provided the answer very much while $51.85 \%$ of them indicated high. On the other 
hand, $29.63 \%$ of the respondents stated moderate and $3.7 \%$ of the respondents said very little. As indicated in the Table 4 below, $66.66 \%$ of the students think that the Technical Drawing module is a module that will contribute to a high level throughout their educational life. The answers provided by the student to the same question changed as $18.52 \%$ very much, $48.15 \%$ high, $29.63 \%$ moderate and $3.7 \%$ very little at the end of the semester. Furthermore, $66.67 \%$ of the students believed that the Technical Drawingmodule was a module that would contribute to a high level throughtout their education life. To that end, there was no change in this answer compared to the beginning of the semester, as indicated in the Table 4.

Table 4. Evaluation Of The Contribution Of The Technical Drawing Module To Other Vocational Modules

\begin{tabular}{|c|c|c|c|c|}
\hline & \multicolumn{2}{|c|}{$\begin{array}{l}\text { Questionnaire } 1 \text { (at the } \\
\text { beginning of the term ) }\end{array}$} & \multicolumn{2}{|c|}{$\begin{array}{c}\text { Questionnaire 2 (at the end of the } \\
\text { term) }\end{array}$} \\
\hline $\begin{array}{c}\text { Contribution } \\
\text { of TD } \\
(0-100)\end{array}$ & Frequency & Percentage $(\%)$ & Frequency & $\begin{array}{l}\text { Percentage } \\
\quad(\%)\end{array}$ \\
\hline Very Much & 4 & 14,81 & 5 & 18,52 \\
\hline High & 14 & 51,85 & 13 & 48,15 \\
\hline Moderate & 8 & 29,63 & 8 & 29,63 \\
\hline Little & - & - & - & - \\
\hline Very Little & 1 & 3,70 & 1 & 3,70 \\
\hline
\end{tabular}

The students were requested to rate their satisfaction level of entering the "Forest Industry Engineering" department on a scale (i.e. 1-100). The average satisfaction level of male students was 64.47 points, the average of female students' satisfaction level was 67.3 points and the general average of the whole class was determined as 65.51 points out of 100 . At the end of the term, the level of satisfaction was requested again and the average satisfaciton level of male students was 64.71 points while the average of female students' satisfaction level was 74.5 points. Furthermore, the general average of the whole class was observed at 68.33/100. To that end, as provided in Table 5, an increase of 3 points was observed in the average satisfaction score.

Tablo 5. Level Of Satisfaction With Entering a Forest Industry Engineering

\begin{tabular}{c|cc|cc}
\hline & $\begin{array}{c}\text { Questionnaire 1 (at the beginning of } \\
\text { the term ) }\end{array}$ & Questionnaire 2 (at the end of the term) \\
\hline $\begin{array}{c}\text { Forest Indusrtial } \\
\text { Engineering } \\
\begin{array}{c}\text { Satisfaction Level } \\
(\mathbf{0}-100)\end{array}\end{array}$ & Frequency & Percentagee (\%) & Frequency & Percentage (\%) \\
\hline $81-100$ & 6 & 22,22 & 5 & 18,52 \\
\hline $61-80$ & 10 & 37,04 & 12 & 44,44 \\
\hline $41-60$ & 8 & 29,63 & 9 & 33,33 \\
\hline $21-40$ & 1 & 3,70 & - & - \\
\hline $0-20$ & 2 & 7,41 & 1 & 3,7 \\
\hline
\end{tabular}

The open-ended question, which was asked to be answered in both surveys conducted at the beginning and end of the semester was the students' ideas about the contribution of the 
Technical Drawing module. The question is addressed as "How will you benefit from taking a Technical Drawing module as an engineer when you graduate" at the beginning of the semester, when the students have not taken the module yet and did not have much idea about the content of it. Almost all of the class answered this question that it would contribute to their professional development and improve their three-dimensional drawing ability. At the end of the semester, the students were asked the question of "explain the contribution of the Technical Drawing module to you in a few sentences". In general, students indicated that their 3-dimentional understanding has improved and the module has contributed to the ability to look at objects from different perspectives, as well as to think three-dimensionally and creatively while being careful and patient at the same time.

In Figure 1, 3D pictures of parts A, B, C, D, E and F were provided and the students were asked to match the view pictures with $3 \mathrm{D}$ views. In the question where the viewing direction was the same for all the pieces, 18 images were asked to which piece belonged to the front view, top view and left side view drawings that arranged in a mixed order. The number of correct answers provided for the two questionnaires conducted at the beginning and end of the semester is provided under Table 6 . The correct answer average of the whole class was 15.33 correct answers at the beginning of the term while it increased to 16.1 at the end of the term. At the end of the term, furthermore, the rate of students who gave the correct answer increased from $37.04 \%$ to $48.15 \%$.

Table 6. Questionnaire 1 - 3D View Question1

\begin{tabular}{|c|c|c|c|c|}
\hline \multirow[b]{2}{*}{$\begin{array}{c}\text { Number of } \\
\text { correct } \\
\text { answers }\end{array}$} & \multicolumn{2}{|c|}{$\begin{array}{l}\text { Questionnaire } 1 \text { (at the } \\
\text { beginning of the term ) }\end{array}$} & \multicolumn{2}{|c|}{$\begin{array}{c}\text { Questionnaire } 2 \text { (at the end of the } \\
\text { term) }\end{array}$} \\
\hline & Frequency & $\begin{array}{l}\text { Percentage } \\
\quad(\%)\end{array}$ & Frequency & Percentage $(\%)$ \\
\hline 18 & 10 & 37,04 & 13 & 48,15 \\
\hline 16 & 5 & 18,52 & 5 & 18,52 \\
\hline 15 & 4 & 14,81 & 1 & 3,70 \\
\hline 14 & 2 & 7,41 & 4 & 14,81 \\
\hline 13 & 2 & 7,41 & 3 & 11,11 \\
\hline 12 & 1 & 3,70 & - & - \\
\hline 11 & 1 & 3,70 & - & - \\
\hline 10 & - & - & 1 & 3,70 \\
\hline 9 & 1 & 3,70 & - & - \\
\hline 8 & 1 & 3,70 & - & - \\
\hline
\end{tabular}

Another quesiton included in both surveys at the beginning and end of the semester was the visual figure question. The $3 \mathrm{D}$ views of different parts $\mathrm{A}, \mathrm{B}$, and $\mathrm{C}$ were provided under Figure 2. The students were requested to write in the boxes below which parts these 3D drawings, which were provided from different angles, belonged. The correct answer average of the whole class was 7.63 correct answers at the beginning of the term and 8.88 correct answers at the end of the term. Indeed, $63 \%$ of the students answered all of the 3D views from different angles (i.e. 9/9) correctly. This is followed by $7 / 9$ correct answers (i.e. 14.81\%). At the end of the semester, $88.88 \%$ of the students answered all of the 3D views from different angles (i.e. 9/9) correctly. $11.11 \%$ of the students, however, made only one mistake (i.e. 8/9) (Table 7). 
Table 7. Questionnaire 1 - 3D View Question 2

\begin{tabular}{c|cc|cc}
\hline & \multicolumn{2}{|c|}{$\begin{array}{c}\text { Questionnaire 1 (at the } \\
\text { beginning of the term) }\end{array}$} & \multicolumn{2}{|c}{$\begin{array}{c}\text { Questionnaire 2 (at the end of the } \\
\text { term) }\end{array}$} \\
\hline $\begin{array}{c}\text { Number of } \\
\text { correct } \\
\text { answers }\end{array}$ & Frequency & $\begin{array}{c}\text { Percentage } \\
(\boldsymbol{\%})\end{array}$ & Frequency & $\begin{array}{c}\text { Percentage } \\
(\boldsymbol{\%})\end{array}$ \\
\hline 9 & 17 & 62,96 & 24 & 88,88 \\
\hline 8 & 1 & 3,70 & 3 & 11,11 \\
\hline 7 & 4 & 14,81 & - & - \\
\hline 6 & 1 & 3,70 & - & - \\
\hline 5 & - & - & - & - \\
\hline 4 & 1 & 3,70 & - & - \\
\hline 3 & 1 & 3,70 & - & - \\
\hline 2 & 2 & 7,41 & - & - \\
\hline 1 & - & - & - & \\
\hline
\end{tabular}

In the second survey conducted at the end of the semester, two new questions were adressed to the students. Table 8 and Table 9 below show the distribution of the number of correct answers given to these questions. As illustrated in Table 8, the average correct answer rate of the class was 14 out of 16 in which the images of 4 very similar objects from different angles were asked to be matched as illustrated in Figure 3. In addition, $74.97 \%$ of the students had 14 or more correct answers to this question, in which a total of 16 different views were asked.

Table 8. Questionnaire 2 - 3D View Question 3

\begin{tabular}{ccc}
\hline $\begin{array}{l}\text { Number of } \\
\text { correct answer }\end{array}$ & Frequency & Percentage (\%) \\
\hline 16 & 9 & 33,33 \\
\hline 15 & 4 & 14,81 \\
\hline 14 & 7 & 25,93 \\
\hline 13 & 1 & 3,70 \\
\hline 12 & 2 & 7,41 \\
\hline 11 & 3 & 11,11 \\
\hline 6 & 1 & 3,70 \\
\hline
\end{tabular}

In the last question of the end-of-term survey, there were three randomly selected and placed view figures of four different objects whose 3D views were provided. In the question, it was questioned to which object these views belonged and which view (front/top/left side) they were. The scores of eight different view belonging to the given four objects were assessed as follows: The scoring for the C-top view correct answer was as follows: C: 0.5 points, top view: 0.5 points. The correct answers to this questions are provided in Table 9. The average of the correct answers to the question was 5.55 out of 8 . Approximately $63 \%$ of the students had 5 or more correct answers from 8 assessments (Figure 4 and Table 9). 
Table 9. Questionnaire 2 - 3D View Question 4

\begin{tabular}{ccc}
\hline $\begin{array}{c}\text { Number of } \\
\text { correct answers }\end{array}$ & Frequency & Percentage(\%) \\
\hline 8 & 4 & 14,81 \\
\hline 7,5 & 2 & 7,41 \\
\hline 6,5 & 4 & 14,81 \\
\hline 6 & 3 & 11,11 \\
\hline 5,5 & 3 & 11,11 \\
\hline 5 & 1 & 3,70 \\
\hline 4,5 & 4 & 14,81 \\
\hline 4 & 2 & 7,41 \\
\hline 3,5 & 1 & 3,70 \\
\hline 3 & 2 & 7,41 \\
\hline 2 & 1 & 3,70 \\
\hline
\end{tabular}

\section{DISCUSSION AND CONCLUSION}

The aim of this study was to examine the relationship between the spatial intelligences of 3D visual thinking and interpretation abilities of Forest Industry Engineering first year students who had little to no experience in technical drawing.

Spatial intelligence, which is related to vision and visualization, has been defined as a type of intelligence related to visuality and called visuospatial. Three-dimensional perception of objects/parts is an important issue in engineering education. Berkan et al. (2020), for instance, conducted visualization-spatial perception and spatial orientation tests on architecture students at the beginning and end of the term. In this study, the visual-spatial intelligence of the students who started to study in the Forest Industry Engineering department was examined with the help of questionnaires designed in accordance with the concent of the technical drawing module in two different time periods, as the beginning of the term and the end of the term.

The first part of the survey questions consisted of demographic questions. A total of 27 students, 17 boys and 10 girls, participated in the survey. The majority $(74.1 \%)$ of the students who took the module and participated in the survey were students born in 1999 and 2000. The average age was determined as 21 . The province where $85 \%$ of the student participating in the survey lived before university was Istanbul and the majority (i.e. 48.15\%) of them were the graduates of Anatolian High Schools (government high schools teaching in a foreign language) In the second part of the questionnaire, there were questions pertaining to the interest in the department, the reasons for choosing the department, and the level of interest in technical drawing and computers. The reasons why students prefer the Department of Forest Industry Engineering were concentrated in the following three options: (i) I chose it consciously because I knew the department (29.62\%), (ii) I chose because I was undecided (25.93\%) and I chose because of Istanbul University's reputation (\%25.93). It should be noted that $96.3 \%$ of the students had never taken a Technical Drawing or similar module from another educational institution (high school, modules, etc.) other than the faculty, and $89 \%$ of them take the Technical Drawing module for the first time.

It is determined that $59.26 \%$ of the student had a moderate or higher interest in computer games and $59.25 \%$ in computer software. The most played game genre was action games with $41 \%$ 
which was followed by sports, strategy, information, educative and racing games respectively, with a rate of $25 \%$ and above. It was also seen that $59.26 \%$ of the students play computer games for a maximum of 2 hours and more than 2 hours a day.

At the beginning of the term, it was seen that the average level of interest of the class in the Technical Drawing module was 60 points and the interest level of the female students in the lecture was higher than the male students (i.e. approximately 20 points). At the end of the term, the average level of interest of the students in the Technical Painting module increased to 70.63 points. The average of interest level of female students increased from 73 to 84.7 points, and the average of interest level of male students increased from 52.5 to 62.35 points. At the end of the term, it was monitored that the students' interest in the module increased by approximately 10 points.

The rate of students who believed that the Technical Drawing module requires special talent was $44.44 \%$ at the beginning of the term, while this rate decreased to $37.04 \%$ at the end of the term. Female students thought that no special skills were required for Technical Drawing module at a higher rate than male students. However, looking at the general average, more than half of the students thought that they did not require special talents/abilities. While the rate of students who thought that the Technical Drawing module did not require special talents was approximately $56 \%$ at the beginning of the term, which then later increased to $63 \%$.

To the question of "to what extent do you think the Technical Drawing module will contribute to other vocational modules you will take during your engineering education", $66.66 \%$ of the students responded that the technical drawing module is a module that will contribute to their whole education life at a high level. There was no change in this answer at the beginning and end of the semester.

The students were then asked to rate their satisfaction level of entering the "Forest Industry Engineering" department between 0-100 points on a Likert scale. The average satisfaction level of male students was 64.47 points, the average of female students' satisfaction level was 67.3 points and the general average of the whole class was determined as 65.51 points out of 100 . At the end of the term, the level of satisfaction was requested again and the average satisfaciton level of male students was 64.71 points while the average of female students' satisfaction level was 74.5 points. Furthermore, the general average of the whole class was observed at 68.33/100. To that end, an increase of 3 points was observed in the average satisfaction score. The students' ideas about the contribution of the Technical Drawing module to them were similar and close to each other throughout the module. The majority of the class responded that the module would contribute to their professional development and improve their threedimensional drawing ability. In general, students indicated that their perspective understanding has improved and the module has contributed to the ability to look at objects from different perspectives, as well as to think three-dimensionally and creatively while being careful and patient at the same time.

Figure questions, in which visual spatial skills were assessed, consisted of two parts in the First Questionnaire. In the first question, 3D view pictures were provided and the students were asked to match the views of 6 different parts to which part they belong. While the correct answer average of the class was 15.33 at the beginning of the term, it increased to 16.1 at the end of the term. It is also observed that the rate of students who provided the correct answer at the end of the term increased by $11 \%$ from $37.04 \%$ to $48.15 \%$. 
In the second question of the First and Second Questionnaires, a question was asked in which the object, whose 3D view was provided, was evaluated from different angles. In the question in which nine different views were asked, the average correct answers increased to 8.88 from 7.63. While rate of students who answered all of the 3D views correctly (i.e. 9/9) at the beginning of the term was $63 \%$, while this rate increase to $88.88 \%$ at the end of the term. At the end of the term, it is also observed that the success of $3 \mathrm{D}$ view evaluation has increased.

In the second survey conducted at the end of the term, two new question sets were adressed to the students. The average correct answer rate of the class was 14 in the 16-answer question where the images of four very similar objects from different angles were asked to be matched. In this question where 16 different views were addressed, $74.07 \%$ of the students gave 14 or more correct answers. In the last question of the Second Questionnaire, there were three randomly selected and placed view figures of four different objects whose 3D views were provided. In the quesiton, it was questioned to which object these views belonged and which view (front/top/left side) they were. The average of correct answers was 5.55 out of 8 . Approximately $63 \%$ of the students gave 5 or more correct answers out of 8 .

Considering the results in general, it is seen that the students' ideas about the Technical Drawing module and their 3-dimensional visiual abilities have changed and developed positively at the end of the term. Yazic1 (2016) also evaluated the students' 2D and 3D perception skills in his study and stated that there were positive developments with the results. They also made evaluations supporting this result in the answers they provided in the questionnaire.

Technical drawing/technical art is one of the modules that an engineering student should use effectively. In the Technical Drawing module, basic technical drawing studies are carried out to define and draw objects in two and three dimensions. As Ferguson (1992) also contends, the ability to think in three dimensions should be one of the main characteristics of an engineer candidate. This study showed that the tehnical drawing module contributed to the development of an engineer candidate's visuospatial skills.

This study can be repeated on the final year students and Forest Industry Engineering departments of other universities to reveal the development/transfirmation levels of the students through their university life. Furthermore, this study was conducted during the faceto-face education process before the COVID-19 pandemic that affected the whole world. It is believed that it will be useful to conduct research on this subject for students who are involved in the distant/online learning process during the pandemic period. In addition, the results of this study can be utilized as data in the studies of improving technical drawing module education and training processes.

\section{AUTHOR CONTRIBUTIONS}

Emel ÖZTÜRK: Original idea, study design, statistical analysis, obtaining and organizing the data, interpret the data, manuscript preparation, writing the manuscript, supervising the study, reviewing the manuscript. Emine Seda ERDINNLER: Original idea, study design, supervising the study, translation, interpret the data, reviewing the manuscript. Sedanur ŞEKER: Original idea, study design, obtaining and organizing the data, translation, writing the manuscript, 
manuscript preparation, reviewing the manuscript. All authors discussed the results and contributed to the final manuscript.

\section{REFERENCES}

Alcañiz, M., Contero, M., Pérez-López, D. C., Ortega, M. 2010. Augmented Reality Technology for Education. New Achievements in Technology Education and Development, 247-256.

Adiska, D.N., Liliasari, and Musthapa, I., 2021. Learning nucleophilic substitution reaction based on 3Dvisualization to improve students' critical thinking ability. International Conference on Mathematics and Science Education. 1806 (2021) 012182 IOP Publishing doi:10.1088/1742-6596/1806/1/012182.

Berkan, S.T., Öztaş, S.K.,Kara, F.I., Vardar, A.E., 2020. The Role of Spatial Ability on Architecture Education, Design and Technology Education: An International Journal, October.

Castro-Alonso, J.C., David, H., David, U., Uttal, H., 2019. Spatial Ability for University Biology Education. In book: Advances in Human Factors in Training, Education, and Learning Sciences, January 2019 ,DOI: 10.1007/978-3-319-93882-0_28.

Esparrachiari, S., 2005. Virtual Reality Learning Tool for Electrophysiology. Proceedings of the II Workshop TIDIA FAPESP, Sao Paolo, pp. 6-12.

Ferguson, E. S.,, 1992. A sophisticated, thoughtful, and provocative analysis of thenature of engineering.Engineering and the Mind's Eye, MIT Press.

Gardner, H., 2011. Frames of mind: the theory of multiple intelligences. (3rd Ed.), Basic Books.

Górska, R., 2005. Spatial Imagination an Overview of the Longitudinal Research at Cracow University of Technology. Journal for Geometry and Graphics, vol 9, no 2, pp 201-208.

Gómez-Tone H.C. , Escapa J.B. , Escapa B.P. and Martin-Gutierrez J., 2021. The Drawing and Perception of Architectural Spaces through Immersive Virtual Reality. Sustainability, 13, 6223. https://doi.org/10.3390/su13116223

Haniff, D. J., Baber, C., 2003. User evaluation of augmented reality systems. Proceedings of The Seventh International Conference on Information Visualization, 505-511. Doi:10.1109/IV.2003.1218032.

Hsi, S., Linn, M.C., Bell, J.E., 1997. The Role of Spatial Reasoning in Engineering and Design of Spatial Instruction. Journal of Engineering Education 86, 151-158.

Kaufmann, H., 2004. Geometry education with augmented reality. Unpublished doctoral dissertation, Vienna University of Technology, Vienna, Austria.

Kayhan, E.B., 2005. Investigation of high school students' spatial ability. Yayımlanmamış doktora tezi, ODTÜ, Ankara.

Li, Y., Yang Y., Yao, Z., Xu, G., 2020. Virtual 3D environment for exploring the spatial ability of students. Virtual Reality \& Intelligent Hardware 2(6):556-568. DOI: 10.1016/j.vrih.2020.08.001.

Linn, M.C., Petersen, A.C., 1985. Emergence and characterization of gender differences in spatial abilities: A metaanalysis. Child Development, 56, 1479-1498.

Machuca, M. D. B., Stuerzlinger, W.,Asente, P., 2019. The Effect of Spatial Ability on Immersive 3D Drawing. C\&C '19 June 23-26, San Diego, CA, USA. https://doi.org/10.1145/3325480.3325489

McGee, M.G., 1979. Human spatial abilities: Sources of sex differences. New York: Praeger. 
Olkun, S., Altun, A., 2003. The relationship between primary school students' experiences and their spatial thinking and geometry achievements. The Turkish Online Journal of Educational Technology, 2(4), 1-7.

Prieto, G., Velasco, A.D. 2002a. Predicting Academic Success of Engineering Students in Technical Drawing from Visualization Test Scores. J. Geometry Graphics 6, 99-109.

Prieto, G., Velasco, A.D. 2002b. Construction of a visualization test based on Cognitive Psychology. Avaliaçao Psicologica: Interamerican Journal of Psychological Assessment, ISSN-e 2175-3431, ISSN 1677-0471, Vol. 1, No. 1, pages, 39-47.

Rahmawati, Y., Dianhar, H., Arifin, F.,2021. Analysing Students' Spatial Abilities in Chemistry Learning Using 3D Virtual Representation, Educ. Sci., 11, 185. https://doi.org/10.3390/educsci11040185

Roussou, M., 2000. Immersive Interactive Virtual Reality and Informal Education. Foundation of the Hellenic World [online], vol. 5, [cit. 2012-02-23].

Saito, T., Suzuki, K., Jingu, T., 1998. Relations between Spatial Ability evaluated by a mental Cutting Test and Engineering Graphics Education. Proc. 8th ICECGDG Austin/Texas. pp. 231-235.

Schanbel, M. and Kvan, T., 2003. Spatial understanding in immersive virtual environments. International Journal of Architectural Computing. 1, 3, s. 435-448. ISSN 1478-0771.

Skagerlund, K., Forsblad, M., Tinghög G., Västfjäll, D., 2020. Decision-making competence and cognitive abilities: Whichabilities matter, Journal of Behavioral Decision Making, March 2021, DOI: 10.1002/bdm.2242.

Sorby, S., 2007. Developing 3D spatial skills for engineering students. Australasian Journal of Engineering Education [online], vol. 13, no 1

Sternberg, R.J., 1990. Metaphors of mind: Conceptions of the nature of intelligence. USA: Cambridge University Press.

Valera, A.R., Sarah, O. N., Alenogines, L., 2021. Effectiveness Of 3D Solid Model On Improving Spatial Visualization Ability For Technical Drafting Students. Sci. Int.(Lahore). 33(3),159-164, ISSN 1013-5316;CODEN: SINTE 8.

Wang, X., Dunston, P. S., 2006. Compatibility issues in Augmented Reality systems for AEC: An experimental prototype study. Automation in Construction, 15(3), 314-326.

Yazic1, E., 2016. The Relationship Between Cognitive Style and Visual Spatial Intelligence Of First Year Architectural Students. Kastamonu Eğitim Dergisi, 25 (2), 805-820. 